Article

\title{
Antibacterial, Antifungal and Cytotoxic Isoquinoline Alkaloids from Litsea cubeba
}

\author{
Wei Zhang ${ }^{1}$, Jin-Feng Hu ${ }^{2}$, Wen-Wen Lv ${ }^{1}$, Qing-Chun Zhao ${ }^{1}$ and Guo-Bing Shi ${ }^{1, *}$ \\ 1 Department of Pharmacy, General Hospital of Shenyang Military Area Command, \\ Shenyang 110840, China \\ 2 Department of Pharmacology, Institute of Materia Medica, Chinese Academy of Medical Sciences \\ and Peking Union Medical College, Beijing 100050, China \\ * Author to whom correspondence should be addressed; E-Mail: gbshi@sohu.com.
}

Received: 21 September 2012; in revised form: 6 October 2012 / Accepted: 19 October 2012 / Published: 1 November 2012

\begin{abstract}
Five novel isoquinoline alkaloids ( + )- $N$-(methoxylcarbonyl)- $N$-nordicentrin (1), (+)- $N$-(methoxylcarbonyl)- $N$-norpredicentrine (2), (+)- $N$-(methoxylcarbonyl)- $N$-norbulbodione (3), and (+)- $N$-(methoxylcarbonyl)- $N$-norisocorydione (4), and (+)-8-methoxyisolaurenine- $N$ oxide (5) were isolated, together with one known compound, $(+)-N-($ methoxylcarbonyl)$\mathrm{N}$-norglaucine (6), from a $70 \% \mathrm{EtOH}$ extract of the barks of Litsea cubeba. Structural elucidation of all the compounds were performed by spectral methods such as 1D- and 2D-NMR, IR, UV, and HRESIMS. Alkaloids 1, 2 and $\mathbf{6}$ showed antimicrobial activity against the bacterium $S$. aureus and two fungi (A. alternata and C. nicotianae). Compounds 3,4 exhibited significant cytotoxicity against all of six tested tumor cell lines.
\end{abstract}

Keywords: Litsea cubeba; Lauraceae; isoquinoline alkaloids; antibacterial; antifungal; cytotoxicity

\section{Introduction}

Litsea cubeba (Lauraceae ) is a 3- to $10 \mathrm{~m}$ evergreen tree or shrub widely distributed in Southeastern Asia, Southern China, Japan, and Taiwan [1,2]. L. cubeba can be used as a flavoring or herbal medicine. As a flavoring, it gives a unique flavor resembling that of a mixture of pepper, ginger, and citrus. It is used as a flavor enhancer in foods, cosmetics, and cigarettes [3,4]. The bark of L. cubeba has been used in oriental traditional medicine for the treatment of atopic eczema and coronary heart disease, and its 
antioxidant activities and antimicrobial activities against Staphylococcus aureus, Salmonella typhi, and Pseudomonas aeruginosa have been reported [5-7]. The essential oil from L. cubeba has good fungicidal activities against Sclerotinia sclerotiorum, Thanatephorus cucumeris, Pseudocercospora musae and Colletotrichum gloeosporioides [8,9]. Various types of alkaloids have been isolated from this plant [10-12]. Litebamine and its $\mathrm{N}$-homologues possess acetylcholinesterase activity [13]. Moreover, litebamine can inhibit platelet aggregation, adenosine 5'-triphosphate (ATP) release and thromboxane B2 formation induced by arachidonic acid and collagen in rabbit platelets [14]. In the present paper, chromatographic separation of an aqueous EtOH extract of the barks of L. cubeba has yielded five novel isoquinoline alkaloids, namely (+)- $N$-(methoxylcarbonyl)- $N$-nordicentrin (1), (+)- $N$-(methoxycarbonyl)- $N$-norpredicentrine (2), (+)- $N$-(methoxyl-carbonyl)- $N$-norbulbodione (3), and (+)- $N$-(methoxycarbonyl)- $N$-norisocorydione (4), and (+)-8-methoxyl-isolaurenine $N$-oxide (5), and one known compound, (+)- $N$-(methoxycarbonyl)- $N$-norglaucine (6) (Figure 1). Their structures were established on the basis of their chromatographic properties, chemical and physicochemical methods. Furthermore, all the triterpenoids were evaluated for their in vitro antibacterial, antifungal and cytotoxic properties.

Figure 1. The structures of compounds 1-6.

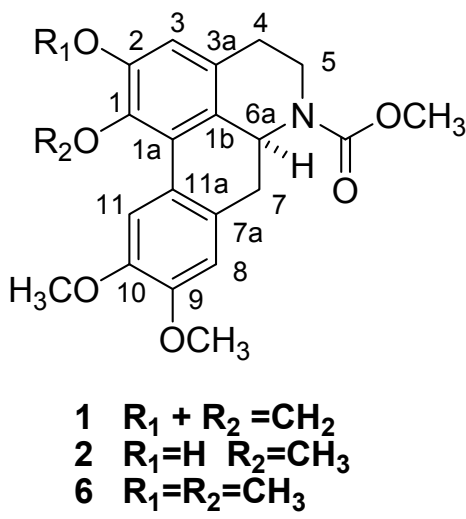

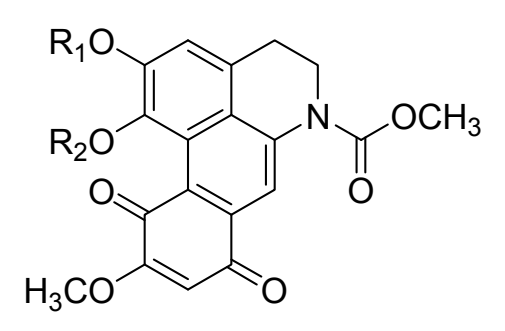

$3 \mathrm{R}_{1}+\mathrm{R}_{2}=\mathrm{CH}_{2}$

$4 \mathrm{R}_{1}=\mathrm{R}_{2}=\mathrm{CH}_{3}$<smiles>COc1ccc2c(c1OC)C[C@H]1[C@@H](C)CCc3cc4c(c(c3-2)OCO4)[N+]1(C)C</smiles>

5

\section{Results and Discussion}

Compound 1 was obtained as a brown amorphous powder. The HRESIMS displayed a pseudomolecular ion at $\mathrm{m} / z 406.1263[\mathrm{M}+\mathrm{Na}]^{+}$(calcd for $\mathrm{C}_{21} \mathrm{H}_{21} \mathrm{NO}_{6} \mathrm{Na}, 406.1267$ ) consistent with a molecular formula of $\mathrm{C}_{21} \mathrm{H}_{21} \mathrm{NO}_{6}$, corresponding to 12 degrees of unsaturation. Its $\mathrm{UV}$ absorption at $\lambda_{\max }$ 303, 284, and $216 \mathrm{~nm}$ suggested an aporphine alkaloid skeleton with substituents at C-1, C-2, C-9, and $\mathrm{C}-10$ [15]. Its ${ }^{13} \mathrm{C}-\mathrm{NMR}$ spectrum showed 21 carbon signals $\left[\mathrm{OCH}_{3} \times 3, \mathrm{OCH}_{2} \mathrm{O} \times 1, \mathrm{CH}_{2}\left(\mathrm{sp}^{3}\right) \times 3, \mathrm{CH}\right.$ $\left(\mathrm{sp}^{3}\right) \times 1, \mathrm{CH}\left(\mathrm{sp}^{2}\right) \times 3$ and $\mathrm{C}\left(\mathrm{sp}^{2}\right) \times 10$, Table 1]. The ${ }^{1} \mathrm{H}-\mathrm{NMR}$ spectrum of $\mathbf{1}$ exhibited three aromatic singlets at $\delta_{\mathrm{H}} 6.86(\mathrm{H}-3), 6.78(\mathrm{H}-8)$, and $8.16(\mathrm{H}-11)$, a methylenedioxy signal at $\delta_{\mathrm{H}} 6.18$, and three methoxys $\left(\delta_{\mathrm{H}} 3.69,3.90\right.$, and 3.93). The IR absorption at $1665 \mathrm{~cm}^{-1}$ and a signal at $\delta_{\mathrm{C}} 157.2$ in the ${ }^{13} \mathrm{C}-\mathrm{NMR}$ spectrum evidenced the presence of a carbamate moiety [16]. The position of the carbamate group at $N-6$ was supported by the HMBC correlations (Figure 2$)$ of $\delta_{\mathrm{C}} 157.2$ with $\delta_{\mathrm{H}} 3.69(3 \mathrm{H}, \mathrm{s}, \mathrm{OMe})$, $4.70(1 \mathrm{H}, d d, J=13.8,3.8 \mathrm{~Hz}, \mathrm{H}-6 \mathrm{a}), 4.42(1 \mathrm{H}, m, \mathrm{H}-5 \mathrm{a})$, and $2.98(1 \mathrm{H}, m, \mathrm{H}-5 \mathrm{~b})$. Meanwhile, in the ${ }^{13} \mathrm{C}-\mathrm{NMR}$ spectra of $\mathbf{1}$, signals of C-7 and -CO appeared as broad peaks due to the stereo-hindrance effect of methyl ester with $\mathrm{C}-7$ on the NMR time scale at room temperature, and signals sharpened when measured under heating conditions $\left(50^{\circ} \mathrm{C}\right)$. The positions of two other methoxys were assigned based on 
the NOESY spectrum (Figure 2). The NOE correlations of H-8 and H-11 with the signals of two $\mathrm{OCH}_{3}$ ( $\delta_{\mathrm{H}} 3.90$ and 3.93, respectively) positioned two methoxys at $\mathrm{C}-9$ and $\mathrm{C}-10$, which was further supported by the HMBC of C-9 $\left(\delta_{\mathrm{C}} 147.2\right)$ with $\mathrm{OCH}_{3}\left(\delta_{\mathrm{H}} 3.90\right)$ and $\mathrm{C}-10\left(\delta_{\mathrm{C}} 148.0\right)$ with $\mathrm{OCH}_{3}$ $\left(\delta_{\mathrm{H}} 3.93\right)$ that the two $\mathrm{OCH}_{3}$ respectively (Figure 2). These data showed similarities to those of (+)- $N$-(methoxycarbonyl)- $N$-norglaucine (6). The stereochemistry of C-6a was determined to be $S$ by its positive specific rotation $\left([\alpha]_{D}^{23.3}=+96.13\right)$ [17]. Therefore, compound $\mathbf{1}$ was identified as $(+)-N$-(methoxycarbonyl)- $N$-nordicentrin.

Figure 2. Key $\mathrm{HMBC}(\frown)$ and ${ }^{1} \mathrm{H}-{ }^{1} \mathrm{H} \operatorname{COSY}(\longleftrightarrow)$ correlations of compounds $\mathbf{1}$ and $\mathbf{5}$.

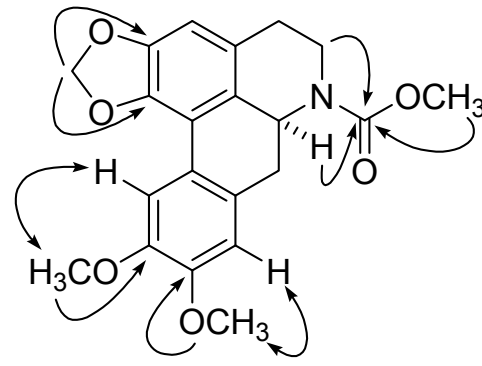

1

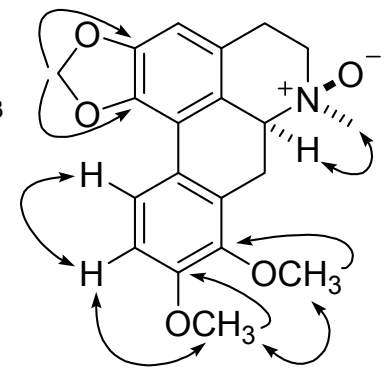

5

Compound 2 was obtained as a brown amorphous powder. The EIMS afforded a molecular weight of $m / z=385$, and its HR-ESI-MS revealed the $[\mathrm{M}+\mathrm{Na}]^{+}$peak at $m / z=408.1422$ (calcd. for $\mathrm{C}_{21} \mathrm{H}_{23} \mathrm{NO}_{6} \mathrm{Na}$. 408.1423), corresponding to the molecular formula $\mathrm{C}_{21} \mathrm{H}_{23} \mathrm{NO}_{6}$. Comparing the ${ }^{1} \mathrm{H}$ - and ${ }^{13} \mathrm{C}-\mathrm{NMR}$ data of $\mathbf{2}$ with those of compound 1, the data were almost identical. The only significant difference was that the signals of the methylenedioxy moiety at $\mathrm{C}-1$ and $\mathrm{C}-2$ was replaced by a $\mathrm{OH}$ and $\mathrm{OMe}$ groups in compound 2. The HMBC correlations of C-1 $\left(\delta_{\mathrm{C}} 144.8\right)$ with $\mathrm{OCH}_{3}\left(\delta_{\mathrm{H}} 3.56\right)$ indicated the location of $\mathrm{MeO}$ and $\mathrm{OH}$ at C-1 and C-2 respectively, which was confirmed by the downfield shift of C-2 from $\delta_{\mathrm{C}}$ 146.8 to 150.5 . On the basis of the observation of NOESY data similar to those of 1 and the positive specific rotation $\left([\alpha]_{D}^{23.3}=+258.7\right.$ [17], the stereochemistry of 2 was expected to be the same. Accordingly, the structure of 2 was established as $(+)-N-($ methoxycarbonyl)- $N$-norpredicentrine.

Compound 3, a violet amorphous powder, exhibited a molecular formula of $\mathrm{C}_{20} \mathrm{H}_{15} \mathrm{NO}_{7}$, based on the HRESIMS spectrum which showed a pseudomolecular ion at $\mathrm{m} / z$ 404.0743 [M+Na] ${ }^{+}$(calcd. 404.0746). The ${ }^{1} \mathrm{H}-\mathrm{NMR}$ spectrum showed singlet signals for three aryl protons $\left(\delta_{\mathrm{H}} 6.91,6.88\right.$, and 5.92), two OMe $\left(\delta_{\mathrm{H}} 3.71\right.$ and 3.85), one methylenedioxy $\left(\delta_{\mathrm{H}} 6.20\right)$, and two triplets for two vicinal coupled methylenes $\left[\delta_{\mathrm{H}} 2.63,2.88(\mathrm{H}-4)\right.$ and $\left.2.99,4.43(\mathrm{H}-5)\right]$. The IR spectrum exhibited a conjugated carbonyl absorption $\left(1654 \mathrm{~cm}^{-1}\right)$, and the ${ }^{13} \mathrm{C}-\mathrm{NMR}$ spectrum displayed two carbonyl signals at $\delta_{\mathrm{C}} 178.3$ and 186.4, similar to the 1,4-dicarbonyl signals in $N$-norbulbodione [18]. The HMBC correlations of $\delta_{\mathrm{C}}=156.2$ with $\delta_{\mathrm{H}} 3.71$ $(3 \mathrm{H}, s, \mathrm{OMe}), 2.99(1 \mathrm{H}, m, \mathrm{H}-5 \mathrm{a})$, and $4.33(1 \mathrm{H}, m, \mathrm{H}-5 \mathrm{~b})$ indicated the presence of a $N$-carbamate group. The methylenedioxyl unit was positioned between $\mathrm{C}-1$ and $\mathrm{C}-2$, and the methoxyl at C-10, respectively, based on the HMBC correlations of the proton signal of methylenedioxy with $\mathrm{C}-1$ and $\mathrm{C}-2$, and of the methoxyl signal $\left(\delta_{\mathrm{H}} 3.85\right)$ with $\mathrm{C}-10$, respectively. The positive specific rotation $\left([\alpha]_{D}^{23.3}=+77.8\right.$ indicated stereochemistry of C-6a was determined to be $S$ [19] Thus, Compound 3 was elucidated as (+)- $N$-(methoxycarbonyl)- $N$-norbulbodione. 
Table 1. ${ }^{1} \mathrm{H}-\mathrm{NMR}$ data of compounds $\mathbf{1}-\mathbf{5}$ in $\mathrm{CDCl}_{3}$ ( $\delta$ in ppm and $J$ in $\mathrm{Hz}$ ).

\begin{tabular}{|c|c|c|c|c|c|c|c|c|c|c|}
\hline \multirow{2}{*}{ No. } & \multicolumn{5}{|c|}{$\delta^{1} \mathbf{H}(\mathrm{Hz})$} & \multicolumn{5}{|c|}{$\delta^{13} \mathrm{C}$} \\
\hline & 1 & 2 & 3 & 4 & 5 & 1 & 2 & 3 & 4 & 5 \\
\hline 1 & - & - & - & - & - & 142.8 & 144.8 & 141.7 & 143.8 & 142.7 \\
\hline $1 \mathrm{a}$ & - & - & - & - & - & 127.8 & 128.5 & 127.0 & 127.1 & 121.4 \\
\hline $1 b$ & - & - & - & - & - & 129.9 & 131.6 & 116.0 & 116.1 & 122.1 \\
\hline 2 & - & - & - & - & - & 146.8 & 150.5 & 145.5 & 151.9 & 146.6 \\
\hline 3 & $6.86(s)$ & $6.56(s)$ & $6.88(s)$ & $6.63(s)$ & $6.69(s)$ & 107.5 & 115.3 & 107.3 & 111.0 & 109.6 \\
\hline $3 a$ & - & - & - & - & - & 125.2 & 125.2 & 127.1 & 127.2 & 121.9 \\
\hline 4 & $2.59,2.84(\mathrm{~m})$ & $2.52,2.72(\mathrm{~m})$ & $2.63,2.88(\mathrm{~m})$ & $2.62,2.86(\mathrm{~m})$ & $2.73,3.53(\mathrm{~m})$ & 30.1 & 30.8 & 30.2 & 30.4 & 25.4 \\
\hline 5 & $2.98,4.42(\mathrm{~m})$ & $2.87,4.25(\mathrm{~m})$ & $2.99,4.43(\mathrm{~m})$ & $3.00,4.44(\mathrm{~m})$ & $3.57,3.71(\mathrm{~m})$ & 38.9 & 40.3 & 35.6 & 35.6 & 65.6 \\
\hline $6 a$ & $4.70(d d, 13.8,3.8)$ & $4.55(d d, 13.8,4.0)$ & - & - & $4.40(d d, 13.8,3.8)$ & 51.6 & 53.2 & 139.9 & 140.0 & 72.5 \\
\hline 7 & $2.74,2.84(\mathrm{~m})$ & $2.62,2.75(\mathrm{~m})$ & $6.91(s)$ & $6.96(s)$ & $3.06,3.18(\mathrm{~m})$ & 34.9 & 35.4 & 98.2 & 98.3 & 30.2 \\
\hline $7 \mathrm{a}$ & - & - & - & - & - & 124.0 & 124.1 & 136.5 & 136.5 & 124.8 \\
\hline 8 & $6.78(s)$ & $6.80(s)$ & - & - & - & 109.9 & 111.2 & 186.4 & 186.6 & 142.1 \\
\hline 9 & - & - & $5.92(s)$ & $5.94(s)$ & - & 147.2 & 147.3 & 105.0 & 105.2 & 146.2 \\
\hline 10 & - & - & - & - & $7.02(d, 9.2)$ & 148.0 & 148.2 & 163.8 & 163.9 & 109.6 \\
\hline 11 & $8.16(s)$ & $8.16(s)$ & - & - & $8.66(d, 9.2)$ & 111.5 & 111.5 & 178.3 & 178.5 & 117.4 \\
\hline $11 \mathrm{a}$ & - & - & - & - & - & 129.6 & 129.9 & 117.9 & 118.1 & 128.5 \\
\hline $1-\mathrm{OCH}_{3}$ & - & $3.56(s)$ & - & $3.65(s)$ & - & - & 60.1 & - & 59.8 & - \\
\hline $2-\mathrm{OCH}_{3}$ & - & - & - & $3.90(s)$ & - & - & - & - & 55.7 & - \\
\hline $8-\mathrm{OCH}_{3}$ & - & - & - & - & $4.00(s)$ & - & - & - & - & 60.7 \\
\hline $9-\mathrm{OCH}_{3}$ & $3.90(s)$ & $3.91(s)$ & - & - & $3.98(s)$ & 55.8 & 55.8 & - & - & 56.2 \\
\hline $10-\mathrm{OCH}_{3}$ & $3.93(s)$ & $3.93(s)$ & $3.85(s)$ & $3.88(s)$ & - & 55.9 & 56.0 & 56.4 & 56.6 & - \\
\hline $\mathrm{OCH}_{2} \mathrm{O}$ & $6.18(s)$ & - & $6.20(s)$ & - & $6.20(s)$ & 101.1 & - & 101.3 & & 101.4 \\
\hline $\mathrm{CO}_{2} \mathrm{CH}_{3}$ & - & - & - & - & - & 157.2 & 157.6 & 156.2 & 156.0 & - \\
\hline $\mathrm{CO}_{2} \mathrm{CH}_{3}$ & $3.69(s)$ & $3.72(s)$ & $3.71(s)$ & $3.70(s)$ & - & 52.8 & 53.2 & 52.9 & 52.6 & - \\
\hline $\mathrm{N}-\mathrm{CH}_{3}$ & - & - & - & - & $3.35(s)$ & - & - & - & - & 58.0 \\
\hline
\end{tabular}


Compound 4 was obtained as a violet amorphous powder. Its positive HRESIMS spectrum showed a quasimolecular ion peak at $m / z=420.1055[\mathrm{M}+\mathrm{Na}]^{+}$, consistent with the molecular formula $\mathrm{C}_{21} \mathrm{H}_{19} \mathrm{NO}_{7}$, accounting for 13 degrees of unsaturation. The general features of its IR and NMR spectra closely resembled those of $\mathbf{3}$, except for the chemical shifts of two methoxyls in $\mathbf{4}$ taking the place of the methylenedioxyl between $\mathrm{C}-1$ and $\mathrm{C}-2$ in $\mathbf{3}$, which was confirmed by HMBC correlations from the two methoxyl signal $\left(\delta_{\mathrm{H}} 3.65\right.$ and 3.90$)$ with $\mathrm{C}-1\left(\delta_{\mathrm{C}} 143.8\right)$ and $\mathrm{C}-2\left(\delta_{\mathrm{C}} 151.9\right)$, respectively. The stereochemistry of C-6a was established as $S$ as inferred from its positive specific rotation $\left([\alpha]_{D}^{23.3}=+87.3\right)$ [19]. Thus, the structure of 4 was assigned the name $(+)-N$-(methoxycarbonyl)- $N$-norisocorydione.

Compound 5 exhibited a quasimolecular ion peak at $m / z 378.1315\left([\mathrm{M}+\mathrm{Na}]^{+}\right)$in the high-resolution mass spectrometry, which corresponded to the molecular formula $\mathrm{C}_{20} \mathrm{H}_{21} \mathrm{NO}_{5}$. The UV spectrum showed absorptions at $\lambda_{\max }=304,284$, and $217 \mathrm{~nm}$, characteristic of a 1, 2, 8, 9-substituted aporphine. Its ${ }^{1} \mathrm{H}-\mathrm{NMR}$ spectrum showed a very similar pattern to those of $(+)$-isolaurenine $N$-oxide [16], including a methylenedioxyl $\left(\delta_{\mathrm{H}} 6.20\right)$, two coupled aromatic doublets at $\delta_{\mathrm{H}} 7.02(1 \mathrm{H}, d, J=9.2, \mathrm{H}-10)$ and $8.66(1 \mathrm{H}, d, J=9.2, \mathrm{H}-11)$, an aromatic singlets at $\delta_{\mathrm{H}} 6.69(s)$, two $\mathrm{OCH}_{3}$ singlets at $\delta_{\mathrm{H}} 3.98$ and 4.00 , and three highly downfield shifts of $N-\mathrm{CH}_{3}$ at $\delta_{\mathrm{H}}=3.35(3 \mathrm{H}, s), \mathrm{H}-6 \mathrm{a}$ at $\delta_{\mathrm{H}} 4.40(1 \mathrm{H}, d d, J=13.8$, $3.8 \mathrm{~Hz}$ ), and $\mathrm{H}-5$ at $\delta_{\mathrm{H}} 3.57$ and 3.71 (each $1 \mathrm{H}, m$ ) due to the $N$-oxide. The HMBC correlations of the methylenedioxyl proton signal with $\mathrm{C}-1$ and $\mathrm{C}-2$, and of the two methoxyl signals $\left(\delta_{\mathrm{H}} 3.98\right.$ and 4.00) with C-8 and C-9, respectively, indicated that methylenedioxyl were located between C-1 and C-2, and the methoxyls at C-8 and C-9 respectively. The NOE correlations of $\mathrm{H}-10$ with $\mathrm{H}-11$, and $\mathrm{H}-11$ with $\mathrm{OCH}_{3}\left(\delta_{\mathrm{H}} 3.98, s\right)$ further supported the position of the methoxyl groups at C-8 and C-9. The positive specific rotation $\left([\alpha]_{D}^{23.3}=+88.2\right)$ of 5 indicated an $S$ configuration of C-6a [17], compared with the $R$ configuration of that in $(-)$-isoboldine $\beta$-N-oxide $\left([\alpha]_{D}^{20.0}=-90.3\right)$ [20]. Furthermore, the key NOE correlations of $\mathrm{N}-\mathrm{CH} 3$ with $\mathrm{H}-6$ indicated the $\beta$ - $N$-oxide in 5 (Figure 2). Thus, compound 5 was determined to be (+)-8-methoxyisolaurenine $N$-oxide.

All compounds were tested for their antimicrobial activities the by disc diffusion method by measuring the inhibition zones and for the most active compounds, minimum inhibitory concentration (MIC) values were also determined. Interesting antimicrobial properties were observed (Table 2), showing that alkaloids 1, 2 and $\mathbf{6}$ exhibited antimicrobial activity against the bacterium $S$. aureus and two fungi (A. alternata and C. nicotianae), with MIC values of $0.60-0.80 \mathrm{mM}, 0.74-1.04 \mathrm{mM}$ and $1.41-2.14 \mathrm{mM}$, respectively. Compounds 3,4 have antibacterial activities against $S$. aureus, while compound $\mathbf{5}$ showed weak activity against the fungus A. alternata. Moreover, alkaloids 1-4 and $\mathbf{6}$ possessed higher antibacterial, antifungal activities with lower MIC value than 5. These result suggested that the $\mathrm{N}$-carbamate group may strengthen the antibacterial and antifungal activities of this type of alkaloids.

The in vitro cytotoxic activities of the isolated alkaloids were determined against BGC-823 cells (human gastric carcinoma), HepG2 cells (Human hepatocellular carcinoma), MCF-7 cells (human breast cancer), SGC-7901 cells (human gastric adenocarcinoma), SK-MEL-2 (human skin cancer), and with SK-OV-3 (ovarian) using the revised MTT method. The results are summarized in Table 3. Among the tested compounds, alkaloids 3,4 with two carbonyl groups at C-8 and C-11 exhibited the most potent cytotoxicity against all tested tumor cell lines, with $\mathrm{IC}_{50}$ values of 9.54-12.22 $\mu \mathrm{M}$ and 9.83-11.96 $\mu \mathrm{M}$, respectively. Compounds 1, 2 and $\mathbf{6}$ showed moderate cytotoxicity against the six tumor cell lines, while $\mathbf{5}$ had the weakest activities, with an $\mathrm{IC}_{50}$ value above $70 \mu \mathrm{M}$. 
Table 2. Antimicrobial and antifungal activities (zones of inhibition/and MIC mM, n=3) of compounds 1-6.

\begin{tabular}{cccccccc}
\hline Compound & S.aureus & M. tuberculosis & G. pulicaris & A. alternata & C. nicotianae & P. capsici. & G. amomi \\
\hline $\mathbf{1}$ & $20 / 0.68$ & - & - & $19 / 0.64$ & $18 / 0.80$ & - & - \\
$\mathbf{2}$ & $22 / 0.79$ & - & - & $20 / 0.74$ & $17 / 1.04$ & - & - \\
$\mathbf{3}$ & 16.53 & - & - & - & - & - & - \\
$\mathbf{4}$ & 17.62 & - & - & - & - & - & - \\
$\mathbf{5}$ & - & - & - & 15.35 & - & - & - \\
$\mathbf{6}$ & $17 / 2.14$ & - & - & $19 / 1.41$ & $16 / 1.70$ & - & - \\
Rifampicin & $25 / 0.003$ & $22 / 0.003$ & - & - & - & - & - \\
Nystatin & - & - & $20 / 0.008$ & $17 / 0.007$ & $21 / 0.006$ & $18 / 0.061$ & $19 / 0.010$ \\
\hline
\end{tabular}

-: No activity.

Table 3. Cytotoxicity of compounds $\mathbf{1}-\mathbf{6}$ against six human tumor cell lines $\left(\mathrm{IC}_{50}, \mu \mathrm{M}\right)$.

\begin{tabular}{ccccccc}
\hline \multirow{2}{*}{ Compound } & \multicolumn{7}{c}{ Cell lines } \\
\cline { 2 - 7 } & BGC-823 & HepG2 & MCF-7 & SGC-7901 & SK-MEL-2 & SK-OV-3 \\
\hline $\mathbf{1}$ & 31.87 & 28.09 & 30.13 & 29.49 & 29.70 & 29.45 \\
$\mathbf{2}$ & 30.08 & 30.48 & 29.68 & 30.88 & 27.09 & 30.10 \\
$\mathbf{3}$ & 10.38 & 9.54 & 11.65 & 10.34 & 11.44 & 12.22 \\
$\mathbf{4}$ & 9.83 & 10.38 & 10.81 & 11.86 & 10.59 & 11.96 \\
$\mathbf{5}$ & 83.22 & 86.62 & 78.23 & 76.87 & 85.03 & 92.97 \\
$\mathbf{6}$ & 31.51 & 33.78 & 30.72 & 28.94 & 33.12 & 31.84 \\
Doxorubicin & 0.02 & 0.01 & 0.06 & 0.05 & 0.03 & 0.01 \\
\hline
\end{tabular}

\section{Experimental}

\subsection{General}

Melting points were determined using a Fisher-Johns melting point apparatus (Vernon Hills, Lake, IL, USA). Optical rotations were determined with a JASCO P2000 digital polarimeter (Tokyo, Japan). Ultraviolet (UV) and infrared (IR) spectra were obtained on JASCO V-650 and JASCO FT/IR-4100 spectrophotometers, respectively. The NMR spectra were recorded on a Varian Unity INOVA 600 FT-NMR spectrometer ((Salt Lake City, UT, USA; $600 \mathrm{MHz}$ for ${ }^{1} \mathrm{H}$; $125 \mathrm{MHz}$ for ${ }^{13} \mathrm{C}$, respectively). Chemical shifts were reported using residual $\mathrm{CDCl}_{3}\left(\delta_{\mathrm{H}} 7.26\right.$ and $\left.\delta_{\mathrm{C}} 77.0 \mathrm{ppm}\right)$ and $\mathrm{CD}_{3} \mathrm{OD}\left(\delta_{\mathrm{H}} 3.30\right.$ and $\delta_{\mathrm{C}} 49.0 \mathrm{ppm}$ ) as internal standard. High resolution ESIMS spectra were obtained on a LTQ Orbitrap XL (Thermo Fisher Scientific, Waltham, MA, USA) spectrometer. Silica gel 60 (Merck, Darmstadt, Germany, 230-400 mesh), LiChroprep RP-18 (Merck, 40-63 $\mu \mathrm{m}$ ), and Sephadex LH-20 (Amersham Pharmacia Biotech., Roosendaal, The Netherlands) were used for column chromatography (CC). Precoated silica gel plates (Merck, Kieselgel $60 \mathrm{~F} 254,0.25 \mathrm{~mm}$ ) and precoated RP-18 $\mathrm{F}_{254 \mathrm{~s}}$ plates (Merck) were used for analytical thin-layer chromatography analyses. 


\subsection{Plant Material}

The barks of L. cubeba was collected in the Tongren, Guizhou Province, China, in July 2011. A specimen (201107001A) was identified by one of the authors (Q.C. Zhao) and deposited in the Herbarium of Shengyang Medicine College, Shengyang, China.

\subsection{Extraction and Isolation}

The barks of $L$. cubeba $(9.6 \mathrm{~kg})$ were cut into small pieces and were extracted with $70 \% \mathrm{EtOH}(20 \mathrm{~L} \times 3)$ at room temperature for $24 \mathrm{~h}$ each time. After removal of $\mathrm{EtOH}$ under reduced pressure at $55{ }^{\circ} \mathrm{C}$, the aqueous brownish syrup $(1 \mathrm{~L})$ was suspended in $\mathrm{H}_{2} \mathrm{O}(1 \mathrm{~L})$ and then succesively partitioned with petroleum ether $(1 \mathrm{~L} \times 3)$, chloroform $(1 \mathrm{~L} \times 3)$, and $n$-butanol $(1 \mathrm{~L} \times 3)$ to afford fractions of $43.2 \mathrm{~g}, 57.7 \mathrm{~g}$, and $73.2 \mathrm{~g}$, respectively. The chloroform fraction was further fractionated through a silica gel column (200-300 mesh, $10 \times 80 \mathrm{~cm}, 500 \mathrm{~g}$ ) using increasing volumes of acetone in petroleum ether (b.p. $60-90{ }^{\circ} \mathrm{C}$ ) $(100: 1,50: 1,30: 1,15: 1,10: 1,7: 1,5: 1,3: 1,1: 1, \mathrm{v} / \mathrm{v})$ as the eluent to give 10 fractions according to TLC analysis. Fraction 4 (petroleum ether-acetone 15:1, 3.6 g) was applied to an ODS MPLC column (100 g) and eluted with $\mathrm{MeOH}-\mathrm{H}_{2} \mathrm{O}(20: 80,30: 70,40: 60$, each $500 \mathrm{~mL})$ to yield four subfractions (Fr. 4-1 and Fr. 4-4). Subfraction 4-2 (MeOH- $\mathrm{H}_{2} \mathrm{O}, 350 \mathrm{mg}$ ) was purified by preparative RP-HPLC (ODS column, $250 \times 20 \mathrm{~mm}$ ) using $\mathrm{MeOH}-\mathrm{H}_{2} \mathrm{O}(25: 75)$ as mobile phase to obtain 1 (71 mg). Subfraction 4-2 $\left(\mathrm{MeOH}-\mathrm{H}_{2} \mathrm{O}, 350 \mathrm{mg}\right.$ ) was chromatographed by a Sephadex LH-20 column eluted with $\mathrm{MeOH}-\mathrm{H}_{2} \mathrm{O}$ (50:50), and purifed by preparative RP-HPLC (ODS column, $250 \times 20 \mathrm{~mm}$ ) using $\mathrm{MeOH}-\mathrm{H}_{2} \mathrm{O}(30: 70)$ as mobile phase to yield $3(88 \mathrm{mg})$ and 6 (75 mg). Subfraction 4-4 (MeOH- $\mathrm{H}_{2} \mathrm{O}$ 40:60, $\left.99 \mathrm{mg}\right)$ was purified by preparative RP-HPLC (ODS column, $250 \times 20 \mathrm{~mm}$ ) eluting with $\mathrm{MeOH} / \mathrm{H}_{2} \mathrm{O}(22: 78)$ to get $4(57 \mathrm{mg}$ ). Fraction 5 (petroleum ether-acetone 30:1, $1.3 \mathrm{~g}$ ) was applied to an ODS column eluted with MeOH-H $\mathrm{H}_{2} \mathrm{O}(30: 70,40: 60,50: 50)$ to provide three subfractions (Fr. 5-1 and Fr. 5-3), Subfraction 5-2 $\left(\mathrm{MeOH}-\mathrm{H}_{2} \mathrm{O} 20: 80,226 \mathrm{mg}\right)$ was was repeatedly chromatographed on silica gel $(150 \mathrm{~g}, 60 \times 2.8 \mathrm{~cm}$, chloroform-methanol, 20:1 $\rightarrow$ 10:1) and then purifed on a Sephadex LH-20 column eluted with $\mathrm{MeOH}-\mathrm{H}_{2} \mathrm{O}(50: 50)$ to afford $2(78 \mathrm{mg})$. Subfraction 5-3 was purified by preparative RP-HPLC (ODS column, $250 \times 20 \mathrm{~mm})$ eluting with $\mathrm{MeOH} / \mathrm{H}_{2} \mathrm{O}(20: 80)$ to get $\mathbf{5}(77 \mathrm{mg})$.

(+)-N-(Methoxycarbonyl)-N-nordicentrine (1): brown amorphous powder. $[\alpha]_{D}^{23.3}=+96.13(c=0.19$, $\mathrm{MeOH})$. UV $\left(\mathrm{CDCl}_{3}\right) \lambda_{\max }(\log \varepsilon) 303$ (4.12), $284(3.90), 216$ (3.89) nm. IR (KBr) $v_{\max } 3030,1705,1665$, 1452, $1255 \mathrm{~cm}^{-1} .{ }^{1} \mathrm{H}-\mathrm{NMR}\left(\mathrm{CDCl}_{3}, 600 \mathrm{MHz}\right)$ and ${ }^{13} \mathrm{C}-\mathrm{NMR}\left(\mathrm{CDCl}_{3}, 125 \mathrm{MHz}\right)$ data see Table 1. EI-MS $m / z$ : $383\left([\mathrm{M}]^{+}\right)$. HR-ESI-MS (pos.) $m / z$ : $406.1263\left([\mathrm{M}+\mathrm{Na}]^{+}, \mathrm{C}_{21} \mathrm{H}_{21} \mathrm{NO}_{6} \mathrm{Na}\right.$. calc. 406.1267).

(+)- $N$-(Methoxycarbonyl)-N-norpredicentrine (2): brown amorphous powder. $[\alpha]_{D}^{23.3}=+258.7(c=0.16$, $\mathrm{MeOH}) . \mathrm{UV}\left(\mathrm{CDCl}_{3}\right) \lambda_{\max }(\log \varepsilon) 304$ (3.73), 283 (4.20), 216 (3.99) nm. IR (KBr) $v_{\max } 3430,1670,1600$, 1525, $1208 \mathrm{~cm}^{-1} .{ }^{1} \mathrm{H}-\mathrm{NMR}\left(\mathrm{CDCl}_{3}, 600 \mathrm{MHz}\right)$ and ${ }^{13} \mathrm{C}-\mathrm{NMR}\left(\mathrm{CDCl}_{3}, 125 \mathrm{MHz}\right)$ data see Table 1. EI-MS $m / z: 385\left([\mathrm{M}]^{+}\right)$. HR-ESI-MS (pos.) $m / z$ : calc. $408.1422\left([\mathrm{M}+\mathrm{Na}]^{+}, \mathrm{C}_{21} \mathrm{H}_{23} \mathrm{NO}_{6} \mathrm{Na}\right.$. calc. 408.1423).

(+)-N-(Methoxycarbonyl)-N-norbulbodione (3): violet amorphous powder. $[\alpha]_{D}^{23.3}=+77.8(c=0.21$, $\mathrm{MeOH})$. UV ( $\left.\mathrm{CDCl}_{3}\right) \lambda_{\max }(\log \varepsilon) 304$ (4.11), 284 (3.81), 217 (4.11) nm. IR (KBr) $v_{\max }$ 3028, 1707, 
1654, 1455, $1251 \mathrm{~cm}^{-1} .{ }^{1} \mathrm{H}-\mathrm{NMR}\left(\mathrm{CDCl}_{3}, 600 \mathrm{MHz}\right)$ and ${ }^{13} \mathrm{C}-\mathrm{NMR}\left(\mathrm{CDCl}_{3}, 125 \mathrm{MHz}\right)$ data see Table 1. EI-MS m/z: $381\left([\mathrm{M}]^{+}\right)$. HR-ESI-MS (pos.) $m / z$ : $404.0743\left([\mathrm{M}+\mathrm{Na}]^{+}, \mathrm{C}_{20} \mathrm{H}_{15} \mathrm{NO}_{7} \mathrm{Na}\right.$. calc. 404.0746).

(+)-N-(Methoxycarbonyl)- $N$-norisocorydione (4): violet amorphous powder. $[\alpha]_{D}^{23.3}=+87.3(c=0.16$, $\mathrm{MeOH})$. UV $\left(\mathrm{CDCl}_{3}\right) \lambda_{\max }(\log \varepsilon) 305$ (4.25), 283 (3.86), 215 (3.98) nm. IR (KBr) $v_{\max } 3025,1710,1510$, 1454, $1245 \mathrm{~cm}^{-1} .{ }^{1} \mathrm{H}-\mathrm{NMR}\left(\mathrm{CDCl}_{3}, 600 \mathrm{MHz}\right)$ and ${ }^{13} \mathrm{C}-\mathrm{NMR}\left(\mathrm{CDCl}_{3}, 125 \mathrm{MHz}\right)$ data see Table 1. EI-MS m/z: 397 ([M] $]^{+}$). HR-ESI-MS (pos.) $m / z$ : 420.1055 ([M+Na $]^{+}, \mathrm{C}_{21} \mathrm{H}_{19} \mathrm{NO}_{7} \mathrm{Na}$. calc. 420.1059).

(+)-8-Methoxisolaurenine $N$-oxide (5): brown amorphous powder. $[\alpha]_{D}^{23.3}=+88.2(c=0.20, \mathrm{MeOH})$. $\mathrm{UV}\left(\mathrm{CDCl}_{3}\right) \lambda_{\max }(\log \varepsilon) 304$ (3.69), 284 (3.77), 217 (4.07) nm. IR (KBr) $v_{\max }$ 3030, 1568, 1213, 1075, $1025 \mathrm{~cm}^{-1}$. ${ }^{1} \mathrm{H}-\mathrm{NMR}\left(\mathrm{CDCl}_{3}, 600 \mathrm{MHz}\right)$ and ${ }^{13} \mathrm{C}-\mathrm{NMR}\left(\mathrm{CDCl}_{3}, 125 \mathrm{MHz}\right)$ data see Table 1. EI-MS: 355 ([M] $\left.]^{+}\right)$. HR-ESI-MS (pos.) $m / z: 378.1315\left([\mathrm{M}+\mathrm{Na}]^{+}, \mathrm{C}_{20} \mathrm{H}_{21} \mathrm{NO}_{5} \mathrm{Na}\right.$. calc. 378.1317).

\subsection{Antimicrobial Activity Bioassay}

All compounds (purity $>90 \%$ ) were screened for their antimicrobial activity in vitro using the disk-diffusion method as described in the literature with minor modifications [19]. Strains including two species of bacteria [Staphylococcus aureus (ATCC-25923), Mycobacterium tuberculosis (ATCC-25177/H37Ra)] and five species of fungi [Gibberella pulicaris (KZN 4207), Alternaria alternata (TX-8025), Colletotrichum nicotianae (SACC-1922), Phytophthora capsici (KACC-40157), Gonatopyricularia amomi (MB-9671)] were used. Rifampicin and nystatin were used as positive controls for antibacterial and antifungal activities, respectively. A disk containing only DMSO was used as the negative control. Medium used in the antimicrobial activity included nutrient agar medium (S. aureus), Dorset egg medium (M. tuberculosis) and Sabouraud dextrose broth (SDB) agar medium (five species of fungi). To each agar plate, an inoculum containing $10^{7}$ bacteria $/ \mathrm{mL}$ or a 0.5 optical density of the McFarland Scale was incorporated. The plates were solidified and sterile filter paper disks (6-mm diameter) were done on each one. Solution of each compound ( $5 \mathrm{mM})$ in DMSO, antibacterial agents (rifampicin $5 \mu \mathrm{M} / \mathrm{mL}$ ), antifungal agents (nystatin $10 \mu \mathrm{M} / \mathrm{mL}$ ), control vehicles (DMSO) were added into too. The plates were aerobically incubated at $37{ }^{\circ} \mathrm{C}$ for $S$. aureus during $18 \mathrm{~h}$, for the five species of fungi during $24 \mathrm{~h}$ and for M. tuberculosis during 15-45 days, and four assays under identical conditions were carried out for each one. The diameter of the inhibition zone was measured for testing of antibacterial and antifungal activities. Experiments were performed in triplicate, and the results are presented as the mean values of the diameters of the inhibitory zones from three runs. The MIC values of the most active compounds, in the previous experiment, were determined using the dilution method in 96-hole plates. The diameters of the inhibitory zones and the MIC value were used as criteria to judge the antimicrobial activity (active: the diameters of the inhibitory zones $\geq 16 \mathrm{~mm}$, MIC $\leq 5 \mathrm{mM}$; moderately active: the diameters of the inhibitory zones are visible, MIC $>5 \mathrm{mM}$; not active: the diameters of the inhibitory zones are invisible). All strains of bacteria and fungi were purchased from Shanghai Institute of Biochemistry \& Cell Biology, Chinese Academy of Sciences (Shanghai, China). 


\subsection{Cytotoxicity Assay in Vitro}

The cytotoxic activities of the isolated compounds were determined using the revised MTT method [21,22] against BGC-823 cells (human gastric carcinoma), HepG2 cells (Human hepatocellular carcinoma), MCF-7 cells (human breast cancer), SGC-7901 cells (human gastric adenocarcinoma), SK-MEL-2 (human skin cancer), and with SK-OV-3 (ovarian), with doxorubicin (DOX, adriamycin, Sigma Chemical Co., St. Louis, MO, USA) as positive control. Cancer cells $\left(4 \times 10^{3}\right.$ cells) suspended in $100 \mu \mathrm{L} /$ well of DMEM medium containing $10 \%$ fetal calf serum were seeded onto a 96 -well culture plate. After $24 \mathrm{~h}$ pre-incubation at $37{ }^{\circ} \mathrm{C}$ in a humidified atmosphere of $5 \% \mathrm{CO}_{2} / 95 \%$ air to allow cellular attachment, various concentrations of test solution were added and cells were incubated for $48 \mathrm{~h}$ under the above conditions. At the end of the incubation, $10 \mu \mathrm{L}$ of tetrazolium reagent was added into each well followed by further incubation at $37^{\circ} \mathrm{C}$ for $4 \mathrm{~h}$. The supernatant was decanted, and DMSO $(100 \mu \mathrm{L} /$ well $)$ was added to allow formosan solubilization. The optical density (OD) of each well was detected using a microplate reader at $550 \mathrm{~nm}$ and for correction at $595 \mathrm{~nm}$. Each determination represented the average mean of six replicates. The $50 \%$ inhibition concentration $\left(\mathrm{IC}_{50}\right.$ value) was determined by curve fitting and was used as criteria to judge the cytotoxicity (active: $\mathrm{IC}_{50} \leq 20 \mu \mathrm{M}$; moderately active: $20 \mu \mathrm{M}<\mathrm{IC}_{50}$ $\leq 70 \mu \mathrm{M}$; not active: $\left.\mathrm{IC}_{50}>70 \mu \mathrm{M}\right)$. All cell lines were purchased from Cell Bank of Shanghai Institute of Biochemistry \& Cell Biology, Chinese Academy of Sciences. Other reagents were purchased from Shanghai Sangon Biological Engineering Technology \& Services Co., Ltd. (Shanghai, China)

\section{Conclusions}

Phytochemical investigation of the $70 \%$ EtOH extract of $L$. cubeba led to the isolation of five novel isoquinoline alkaloids: $(+)-N$-(methoxycarbonyl)- $N$-nordicentrin (1), $(+)-N$-(methoxycarbonyl)- $N$-norpredicentrine (2), (+)- $N$-(methoxycarbonyl)- $N$-norbulbodione (3), (+)- $N$-(methoxycarbonyl)- $N$-norisocorydione (4) and (+)-8-methoxyisolaurenine $N$-oxide (5) and one known compound, (+)- $N$-(methoxycarbonyl)- $N$-norglaucine (6). All the alkaloids were evaluated for their in vitro antimicrobial activities against two species of bacteria and five species of fungi and cytotoxic properties against BGC-823 cells (human gastric carcinoma), HepG2 cells (Human hepatocellular carcinoma), MCF-7 cells (human breast cancer), SGC-7901 cells (human gastric adenocarcinoma), SK-MEL-2 (human skin cancer), and with SK-OV-3 (ovarian). In the antimicrobial activity screening alkaloids 1, 2 and $\mathbf{6}$ exhibited activity against the bacterium $S$. aureus and two fungi (A. alternata and C. nicotianae). Compounds 3, 4 have antibacterial activities against $S$. aureus, while compound $\mathbf{5}$ showed weak activity against the fungus $A$. alternata. In the cytotoxicity bioassays, alkaloids $\mathbf{3 , 4}$ with carbonyl groups at C-8 and C-11 exhibited the most potent cytotoxicity against all tumor cell lines, and compounds $\mathbf{1 , 2}$ and $\mathbf{5 , 6}$ showed rather moderate cytotoxicity against the six tumor cell lines.

\section{References}

1. Liu, T.T.; Yang, T.S. Antimicrobial impact of the components of essential oil of Litsea cubeba from Taiwan and antimicrobial activity of the oil in food systems. Int. J. Food Microbiol. 2012, $156,68-75$. 
2. Huang, C.H.; Huang, W.J.; Wang, S.J.; Wu, P.H.; Wu, W.B. Litebamine, a phenanthrene alkaloid from the wood of Litsea cubeba, inhibits rat smooth muscle cell adhesion and migration on collagen. Eur. J. Pharmacol. 2008, 596, 25-31.

3. Wang, Y.; Jiang, Z.T.; Li, R. Complexation and molecular microcapsules of Litsea cubeba essential oil with $\beta$-cyclodextrin and its derivatives. Eur. Food Res. Technol. 2009, 228, 865-873.

4. Luo, M.; Jiang, L.K.; Zou, G.L. Acute and genetic toxicity of essential oil extracted from Litsea cubeba (Lour.) Pers. J. Food Prot. 2005, 68, 581-588.

5. Hwang, J.K.; Choi, E.M.; Lee, J.H. Antioxidant activity of Litsea cubeba. Fitoterapia 2005, 76, 684-686.

6. Wang, H.; Liu, Y. Chemical composition and antibacterial activity of essential oils from different parts of Litsea cubeba. Chem. Biodivers. 2010, 7, 229-235.

7. Chen, W.Y.; Ko, F.N.; Wu, Y.C.; Lu, S.T.; Teng, C.M. Vasorelaxing effect in rat thoracic aorta caused by laurotetanine isolated from Litsea cubeba Persoon. J. Pharm. Pharmacol. 1994, 46, 380-382.

8. Yang, Y.; Jiang, J.; Qimei, L.; Yan, X.; Zhao, J.; Yuan, H.; Qin, Z.; Wang, M. The fungicidal terpenoids and essential oil from Litsea cubeba in Tibet. Molecules 2010, 15, 7075-7082.

9. Jiang, Z.; Akhtar, Y.; Bradbury, R.; Zhang, X.; Isman, M.B. Comparative toxicity of essential oils of Litsea pungens and Litsea cubeba and blends of their major constituents against the cabbage looper, Trichoplusia ni. J. Agric. Food Chem. 2009, 57, 4833-4837.

10. Wu, Y.C.; Liou, J.Y.; Duh, C.Y.; Lee, S.S.; Lu, S.T. Litebamine, a novel phenanthrene alkaloid from Litsea cubeba. Tetrahedron Lett. 1991, 32, 4169-4170.

11. Lee, S.S.; Lin, Y.J.; Chen, C.K.; Liu, K.C.S.; Chen, C.H. Quaternary Alkaloids from Litsea cubeba and Cryptocarya konishii. J. Nat. Prod. 1993, 56, 1971-1976.

12. Lee, S.S.; Chen, C.K.; Huang, F.M.; Chen, C.H. Two Dibenzopyrrocoline Alkaloids from Litsea cubeba. J. Nat. Prod. 1996, 59, 80-82.

13. Chiou, C.M.; Kang, J.J.; Lee, S.S. Litebamine $N$-homologues: Preparation and antiacetylcholinesterase activity. J. Nat. Prod. 1998, 61, 46-50.

14. Teng, C.M.; Hsueh, C.M.; Chang, Y.L.; Ko, F.N.; Lee, S.S.; Liu, K.C. Antiplatelet effects of some aporphine and phenanthrene alkaloids in rabbits and man. J. Pharm. Pharmacol. 1997, 49, 706-711.

15. Tantisewie, B.; Pharadai, T.; Pandhuganont, M.; Guinaudeau, H.; Freyer, A.J.; Shamma, M. (+)-N-Formylnornantenine, a new aporphine alkaloid from Cyclea atjehensis. J. Nat. Prod. 1989, $52,652-654$.

16. Chen, Y.Y.; Chang, F.R.; Wu, Y.C. Isoquinoline alkaloids and lignans from Rollinia mucosa. J. Nat. Prod. 1996, 59, 904-906.

17. Montgomery, C.T.; Freyer, A.J.; Guinaudeau, H. Shamma, M. (+)- $N$-Methyllaurotetanine- $\beta$ - $N$-oxide from Glossocalyx brevipes. J. Nat. Prod. 1985, 48, 833-834.

18. Lee, S.S.; Chen, C.K.; Chen, I.S.; Chen, C.H. Chemical Constituents from Dehaasia triandra. 1. Three New Alkaloids, Isocorydione, Norisocorydione, and Dehatriphine, from the Leaves. J. Nat. Prod. 1996, 59, 55-58.

19. Espine-Ingroff, A.; White, T.; Pfaller, M.A. Manual of Clinical Microbiology, 7th ed.; American Society for Microbiology: Washington, DC, USA, 1999; pp. 1640-1652. 
20. Lin, F.W.; Wu, P.L.; Wu, T.S. Alkaloids from the leaves of Cryptocarya chinensis hemsl. Chem. Pharm. Bull. 2001, 49, 1292-1294.

21. Jirapast, S.; Serm, S.; Pongpun, S.; Suttira, K.; Jonkolnee, J.A.; Santi, T.P. Two new cytotoxic isomeric indole alkaloids from the roots of Nauclea orientalis. Fitoterapia 2010, 81, 830-833.

22. Zhang, Y.; Wang, J.; Wei, D.; Wang, X.; Luo, J.; Kong, L. Cytotoxic tirucallane C26 triterpenoids from the stem barks of Aphanamixis grandifolia. Phytochemistry 2010, 71, 2199-2204.

Sample Availability: Samples of the compounds 1-6 are available from the authors.

(C) 2012 by the authors; licensee MDPI, Basel, Switzerland. This article is an open access article distributed under the terms and conditions of the Creative Commons Attribution license (http://creativecommons.org/licenses/by/3.0/). 